\title{
Compatibility of Toothed Ascenders with Arborist Climbing Ropes
}

\author{
Brian Kane
}

\begin{abstract}
Climbers are increasingly using ascenders to access trees, both as a substitute for Prusik loops used in footlocking a doubled rope and with the single rope technique. Manufacturers, however, have explicit limitations on use of ascenders, many of which are violated when used in tree climbing. Ascenders were tested on four arborist climbing ropes in a dynamic drop test; impact load and arrest distance were measured. Of 67 tests, arrest distance met the EN 12841-2006 Standard $(\leq 2 \mathrm{~m})$ only 10 times. Impact loads averaged more than five $\mathrm{kN}$, adding a backup friction hitch to the ascender increased impact load to more than six kN. Climbers need to be made aware of the appropriate use of ascenders, and only use compatible ropes.

Key Words. Ascender; Climbing; Rope.
\end{abstract}

A characterization of the rope-ascender interaction is necessary to validate the adoption of ascender use by arborists. In recent years, climbers have incorporated mechanical ascenders into their ascension and climbing systems, as described in popular literature (Jepson 1995; Bridge and Cowell 2009; Clark 2009). Although ascenders are manufactured in accordance with rigorous United States [NFPA 1983-2006 (Anonymous 2006c)] and international [EN 12841-2006 (Anonymous 2006b); BS 567-1997 (Anonymous 1997)] standards, such standards do not guarantee that ascenders designed for use in other disciplines are compatible with typical arborists' tree climbing gear and practices.

Climbers use ascenders in various ascension systems, including as a substitute for a Prusik knot while static footlocking a doubled rope and with the single rope technique (Jepson 1995; Dunlap 2002; Bridge and Cowell 2009). Although replacing Prusiks with ascenders may facilitate ascent into trees and provide many perceived advantages, empirical testing has not yet confirmed them. While the use of ascenders in ascension systems may provide advantages, their use is clearly limited by manufacturers, and it is imperative that climbers understand the limitations of any piece of gear. Ascenders come with explicit warnings in product literature to address limitations, such as the appropriate construction and diameter of rope to use with ascenders. Product literature also warns that a) climbers who use ascenders [which are typically classified as Type B rope grabs by the EN 12841-2006 Standard (Anonymous 2006b)] on a working line, must also be secured by a safety line with a Type A rope grab; and b) climbers must avoid substantial falls that would cause an impact load (Petzl 2010). Popular arboricultural literature offers similar cautions. Common safety recommendations include: backing up ascenders with a friction hitch above the ascender (Blair 1995; Jepson 1995; Tresselt 2006), keeping the cam of the ascender clear of debris (Jepson 2000; Dun- lap 2002; Bridge and Cowell 2009), and avoiding dynamic loads and loads of more than a single person (Blair 1995).

Testing of ascenders by manufacturers has demonstrated that a toothed ascender will cut the sheath of a $13 \mathrm{~mm}$ diameter kernmantle rope at $6.5 \mathrm{kN}$ (Petzl 2010). Bridge and Cowell (2009) presented similar anecdotal evidence, suggesting that manufacturers' recommendations are relevant to the arboricultural use of ascenders.

Despite warnings to use ascenders in accordance with manufacturers' recommendations and accepted standards, questionable use of ascenders occurs in arboriculture. At the International Tree Climbing Championship, many competitors creatively use ascenders in the aerial rescue event, but many such uses are forbidden by manufacturers (E. Carpenter, pers. comm.). Replacement of Prusik loops with ascenders, which creates the potential for a significant fall and impact loading not recommended for use with ascenders (Petzl 2010), is another example of inappropriate use of ascenders in tree climbing. Such use, however, is often depicted in popular arboricultural literature. For example, ascenders shown in Tresselt (2006) are used in conjunction with a lanyard (backed up by a French Prusik) as a substitute for a traditional footlock Prusik. This particular climbing system allows a fall of the length of the lanyard, generating a substantial impact load on the ascender and rope. If a climber were simultaneously secured with a Type A rope grab to a safety line, the risk to the climber would be reduced, but arboricultural ascension and climbing systems infrequently incorporate a safety line. Images in Clark (2009) show ascenders in use on Safety Blue Hi-Vee and XTC-Plus, neither of which is a kernmantle rope as defined by the EN 18911998 Standard (Anonymous 1998) and required by product literature (Petzl 2010). It is not the author's intent to dismiss the value of popular literature in presenting potentially helpful innovations in climbing systems. Such articles are based on years of experience and admonish climbers to incorporate in- 
novations with caution (Adams 2007). Even in Adams (2007), however, ascenders are shown on Poison Ivy, which does not comply with the EN 1891-1998 Standard (Anonymous 1998).

In light of the growing use of ascenders in tree climbing, and the lack of robust empiric data to describe their performance in arboricultural applications, the objective of this study was to determine whether arborist climbing ropes were compatible with commonly used ascenders.

\section{METHODS AND MATERIALS}

In March and April of 2010, Petzl Ascension ascenders were dynamically tested on four arborist climbing ropes and a static rescue rope (Table 1) in an arboricultural setting. The test method was based on the EN 12841-2006

Table 1. Ropes tested in the study, including rated breaking load $(\mathrm{kN})$ and nominal diameter $(\mathrm{mm})$ from manufacturers' literature.

\begin{tabular}{llcc}
\hline Rope & Manufacturer & Rated load & Diameter \\
\hline Blue Streak & Samson & 30.7 & 12.7 \\
Safety Blue & New England & 31.2 & 12.7 \\
Super Static & Sterling & 30.0 & 11.0 \\
Tachyon & New England & 30.3 & 11.5 \\
Velocity & Samson & 26.7 & 11.0 \\
\hline
\end{tabular}

Standard for Type B rope grabs (Anonymous 2006b), with some modifications. The tests represented a reasonable application of the test standard to an arborist's climbing system.

All ropes were tested brand new, in ambient outdoor conditions (which ranged $15-25^{\circ} \mathrm{C}$ ). One of 16 ascendersevenly distributed between right- and left-handed modelswas randomly assigned for each test. Ascenders were attached to the rope being tested and connected to a lanyard [a Lift-All Tuff Edge rounded eye and eye polyester sling (975 $\mathrm{mm}$ long, length of eye $=290 \mathrm{~mm} ; 51 \mathrm{~mm}$ wide; 28 $\mathrm{kN}$ breaking strength)] with a Bourdon steel D-shaped carabiner (76 mm long; $30 \mathrm{kN}$ breaking strength). The other eye of the lanyard was connected to a drop mass with a second Bourdon steel D-shaped carabiner. The drop mass (Figure 1) consisted of a $19 \mathrm{~mm}$ diameter eye bolt (to which the second D-shaped carabiner was connected) inserted through a threaded steel pipe $50 \mathrm{~mm}$ in diameter. The eye bolt was secured firmly in the pipe with a series of nuts and washers. Four $20 \mathrm{~kg}$ iron weights were stacked vertically along the pipe, prior to inserting the eye bolt. The entire assembly weighed $86 \mathrm{~kg}$ and was $335 \mathrm{~mm}$ tall and $441 \mathrm{~mm}$ in diameter.

A figure-eight loop was tied in each rope that was tested and connected with an ISC steel D-shaped carabiner (70 kN breaking strength) to a dynamometer (Dillon EDXtreme $11 \mathrm{kN}$ capacity, accurate to $1 \mathrm{~N}$, recording at $60 \mathrm{~Hz}$ ). A second ISC steel D-shaped carabiner was used to hang the dynamometer from a steel eyebolt $16 \mathrm{~mm}$ in diameter that was secured in a branch approximately 12 $\mathrm{m}$ above the ground in a red oak (Quercus rubra). The branch was $265 \mathrm{~mm}$ in diameter at the point where the eye bolt was installed, $304 \mathrm{~mm}$ in diameter where it attached to the trunk, and oriented 65 degrees from vertical. The eye bolt was inserted through the branch $1524 \mathrm{~mm}$ from the point of attachment. A separate rope was hung on the branch $1798 \mathrm{~mm}$ from the attachment to hold the drop mass with a short piece of throwline (4 $\mathrm{mm}$ in diameter)

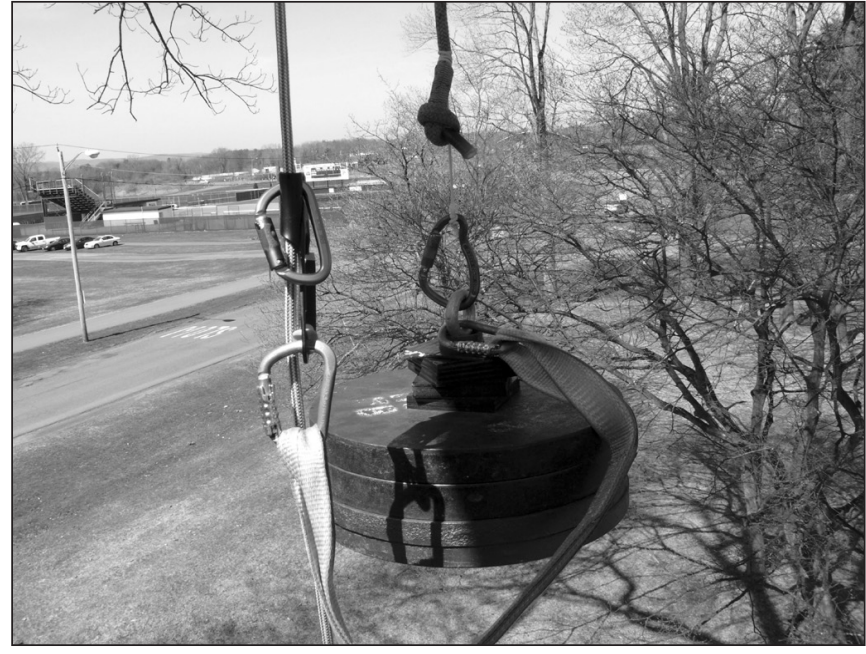

Figure 1. Drop mass (right) and lanyard connected to the ascender (left) and suspended by the short piece of throwline (attached to a larger diameter rope) prior to free fall.

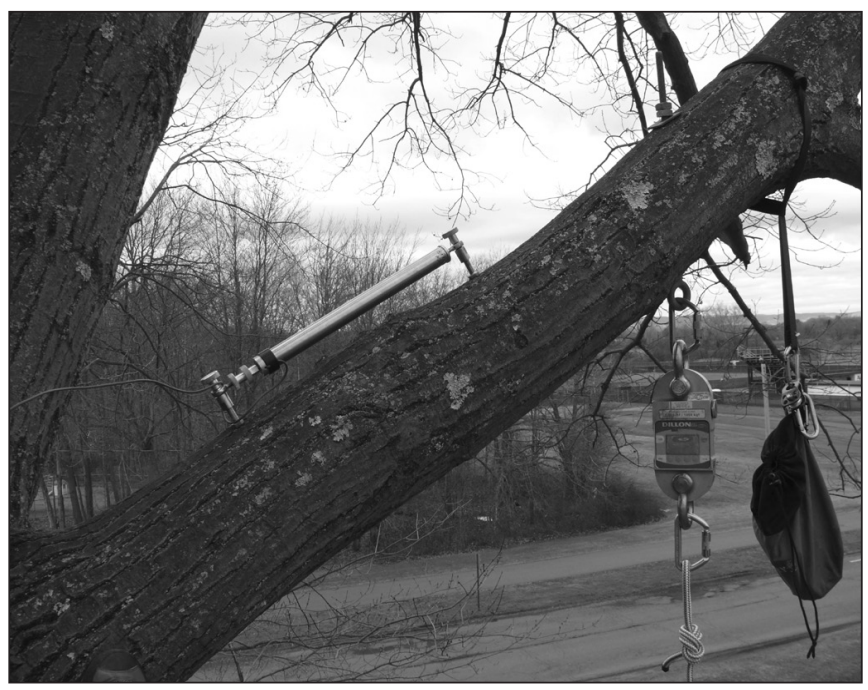

Figure 2. Branch showing, from left to right, strain meter (on top of branch), dynamometer and rope hung from eye bolt, and gear bag indicating location of rope from which drop mass was suspended prior to free falling and loading ascender.

prior to releasing it to load the ascender. The horizontal distance between the eye bolt and the drop mass was $225 \mathrm{~mm}$ (Figure 2).

A large branch was used to minimize the conversion of kinetic energy of the falling mass into strain energy stored in the branch. Greater branch deflection would presumably reduce the impact load on the ascender, and while climbers typically would use a smaller diameter branch, repeated impact loading of a small branch incurred a greater risk of branch failure. Neither would climbers set their rope far away from the branch attachment on smaller diameter branches. Branch deflection at the point of loading was estimated as follows. Tensile strains were measured using a strain gauge [accurate to $0.001 \mathrm{~mm}$ (James and Kane 2008)] installed $300 \mathrm{~mm}$ from the branch attachment (Figure 2), while the branch was statically loaded with the drop mass. From the load, branch dimensions, and geometry of the 
test apparatus, bending stress $(\sigma)$ at the axial mid-point of the strain gauge ( $550 \mathrm{~mm}$ from the branch attachment) was calculated assuming a circular cross section (Lardner and Archer 1994):

$$
\text { [1] } \quad \sigma=32 \mathrm{Pl} /\left(\pi \mathrm{d}^{3}\right)
$$

where $\mathrm{P}$ is the load $(\mathrm{kN}), 1$ is the perpendicular distance from the eye bolt to the mid-point of the strain gauge $(\mathrm{mm})$, and $\mathrm{d}$ is branch diameter $(\mathrm{mm})$. Young's modulus $(\mathrm{E})$ of the branch was calculated from $\sigma$ and strain $(\varepsilon)$ measured during static loading using Hooke's Law $(\mathrm{E}=\sigma / \varepsilon)$; the value was 3.4 MPa. This was a conservative estimate because branch diameter was measured outside the bark, which has smaller values of $\mathrm{E}$ than the wood itself. Determining the deflection of tapered, cantilevered beams loaded at their free end is complex. Instead, branch deflection $(\delta)$ in $\mathrm{mm}$ at the point of loading was conservatively estimated assuming a constant branch diameter (265 $\mathrm{mm}$ ) and the following equation (Lardner and Archer 1994):

[2] $\delta=\mathrm{PL}^{3} /(3 \mathrm{EI})$

where $\mathrm{L}$ is the perpendicular distance from
the eye bolt to the branch attachment, and [3] $\quad \mathrm{I}=\pi \mathrm{d}^{4} / 64$

for a circular cross section. For the geometry and measured $\mathrm{E}$ of the branch, Equations 1, 2, and 3 simplify to:

$$
\text { [4] } \delta=0.5 \mathrm{P}
$$

Impact loading will increase the deflection depending on the magnitude of the impact and stiffness of the branch. Maximum deflection during impact can be estimated from static deflection using the energy approximation method, but this method assumes that the mass of the branch is negligible relative to the drop mass (Werner 1998), which was clearly not true. Substituting the maximum impact load of $8.5 \mathrm{kN}$ (during a test with a Prusik loop) into Equation 4 yields $\delta=3.9 \mathrm{~mm}$; substituting the mean impact load from tests with ascenders of $5.1 \mathrm{kN}$ yields $\delta=2.3 \mathrm{~mm}$. Impact factors in bridge design are typically 1.2 to 1.3 (Kim and Novak 1997). Doubling deflections predicted from Equation 4 still results in minimal values that were considered unlikely to have confounded the test method.

The ascender was attached to the rope according to manufacturer's instructions (Petzl 2010). In accordance with the EN 12841-2006 Standard (Anonymous 2006b), the ascender was statically loaded with the drop mass for 60 seconds prior to releasing the mass (by cutting the throwline), which fell freely until it loaded the ascender, which was $1000 \mathrm{~mm}$ below the dynamometer. This test represented a fall factor (the ratio of fall distance to length of rope in the system) of 1.04. To investigate the effect of adding rope to the climbing system and the increased absorption of energy by the greater length of rope, drop tests were repeated after placing the ascender $2000 \mathrm{~mm}$ below the dynamometer; a fall factor of 0.52 . Limited tests were conducted with the following variations: placing the ascender 4000 $\mathrm{mm}$ below the dynamometer (a fall factor of 0.26 ); increasing the drop mass to $110 \mathrm{~kg}$; tying a backup friction hitch, a Valdotain Tresse (VT), with a Tenex spliced eye-and-eye Prusik 610 $\mathrm{mm}$ long to the rope above the ascender; and replacing the ascender with a 3-wrap, 6-coil Prusik knot and a polyester kern- mantle Prusik loop $8 \mathrm{~mm}$ in diameter and $1000 \mathrm{~mm}$ (including connecting carabiners) long tied around a single or doubled rope. These tests were not included in the quantitative analysis because of the complex nesting of treatments that would have resulted. Results of these tests were presented for qualitative comparison. Impact load and arrest distance (the distance traveled by the ascender-or Prusik knot-prior to stopping) were measured for each test. To comply with the EN 12841-2006 Standard for Type B rope grabs, arrest distance must not exceed two meters.

An analysis of variance (ANOVA) was used to compare impact load and arrest distance between ropes, the length of rope between the dynamometer and ascender (rope length), and their interaction. Each test was replicated a minimum of five times and a maximum of ten times, depending on the amount of rope that was available. Because of the unbalanced design, a general linear model and least squares means were used for the ANOVA, which was conducted in SAS ver. 9.2 (SAS Institute, Cary, North Carolina, U.S.). Arithmetic means were calculated for tests involving qualitative comparisons.

\section{RESULTS}

After several tests on most ascenders, signs of fatigue (typically, bending of the frame that held the rope next to the cam) were evident and the ascenders were retired from testing. For 33 tests with rope length set at $1000 \mathrm{~mm}$, the arrest distance was $\leq 2 \mathrm{~m}$ only three times (all occurred when testing Velocity). For 34 tests with rope length set at $2000 \mathrm{~mm}$, the arrest distance was $\leq 2$ $\mathrm{m}$ seven times: four for Velocity and three for Blue Streak. The arrest distance was least for Velocity and greatest for Tachyon, which was the only rope for which arrest distance was greater with rope length of $1000 \mathrm{~mm}$ than $2000 \mathrm{~mm}$ (Table 2). Arrest distance did not exceed $2 \mathrm{~m}$ for any test with Super Static (Table 3 ). Although the mean arrest distance for Blue Streak tested with $4000 \mathrm{~mm}$ the rope length did not exceed $2 \mathrm{~m}$ (Table 3), arrest distance did exceed $2 \mathrm{~m}$ for two of the five tests. The mean arrest distance for Velocity tested with a VT exceeded $2 \mathrm{~m}$ (Table 3), but for three of the 10 tests, the mean arrest distance was $0.14 \mathrm{~m}$. The arrest distance for single and doubled ropes of Blue Streak tested with a 6-wrap Prusik was quite small (Table 3). Both tests of Blue Streak with $110 \mathrm{~kg}$ completely severed the rope, and the arrest distances for Tachyon and Velocity (Table 3) were $0.72 \mathrm{~m}$ and $1.53 \mathrm{~m}$ greater, respectively, compared to tests with $86 \mathrm{~kg}$.

Across all ropes and rope lengths, impact load did not vary (Table 2). Curiously, impact load was greater with $2000 \mathrm{~mm}$ of rope length than $1000 \mathrm{~mm}$ for Blue Streak, while the opposite was true for Safety Blue (Table 2). Impact load did not differ between rope lengths for Tachyon and Velocity (Table 2). Impact load for Super Static (Table 3) appeared to be similar to impact loads on other ropes tested with $1000 \mathrm{~mm}$ of rope length. Impact load for Blue Streak tested with $4000 \mathrm{~mm}$ of rope length (Table 3) fit between impact loads for Blue Streak tested with 1000 and $2000 \mathrm{~mm}$ of rope length. Impact load for Velocity tested with a backup VT (Table 3) appeared to be greater than impact loads for Velocity tested without a VT. Tests with a Prusik instead of an ascender resulted in the greatest impact loads (Table 3 ). While impact loads of tests on Velocity backed up with a VT appeared to be greater than tests without the VT, the arrest distance was essentially the same with and without the VT, and the same number of tests (3) resulted in an arrest distance less than $2 \mathrm{~m}$. 
Table 2. Least squares means (standard error in parentheses) of arrest distance and impact load classified by the type of rope, rope length, and their interaction. Least squares means followed by the same letter are not statistically different $(P>0.05)$ by Tukey's Honestly Significant Difference test. For combinations of rope and distance, statistical comparisons were made between distances within each rope.

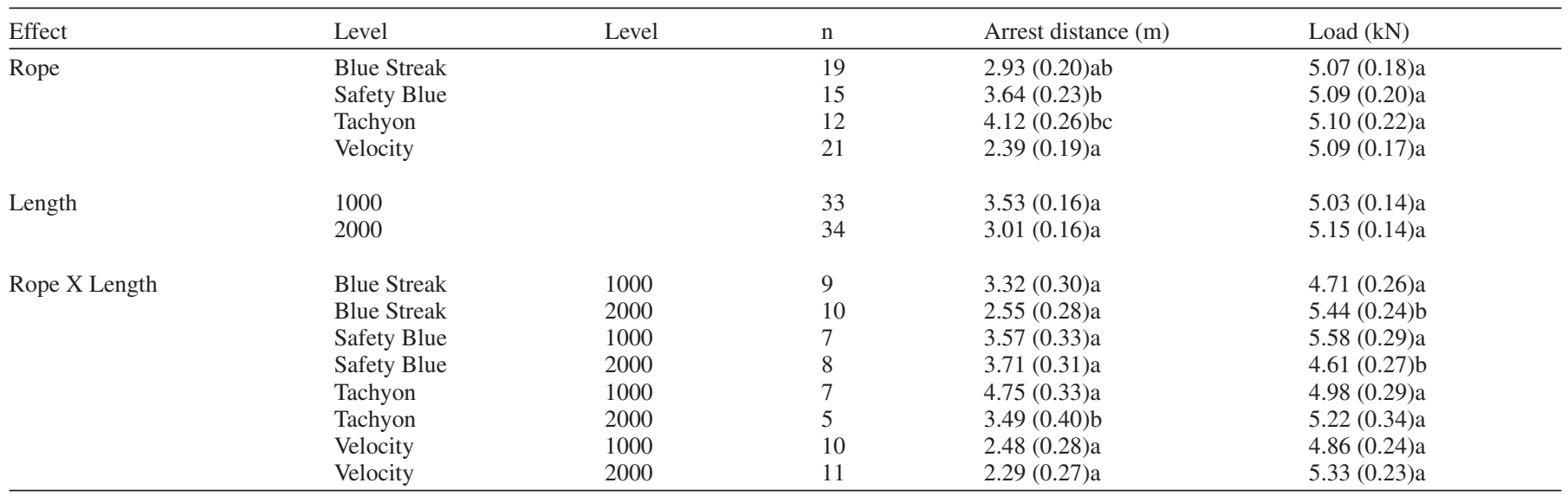

Table 3. Mean arrest distance $(\mathrm{m})$ and impact load $(\mathrm{kN})$ (followed by standard error) for additional drop tests of varying mass $(\mathrm{kg})$, connection to the rope, type of rope, and length of rope $(\mathrm{mm})$ that were not included in the ANOVA. Standard errors were not calculated for tests with fewer than three replications.

\begin{tabular}{|c|c|c|c|c|c|c|}
\hline Mass & Connection & Rope & Length & $\mathrm{n}$ & Arrest distance & Impact load \\
\hline 110 & Ascender & Blue Streak & 1000 & 2 & Failed & 5.11 \\
\hline 110 & Ascender & Tachyon & 1000 & 2 & 5.53 & 4.98 \\
\hline 110 & Ascender & Velocity & 1000 & 2 & 3.99 & 5.06 \\
\hline 86 & Ascender & Super Static & 1000 & 6 & $1.44(0.07)$ & $4.64(0.16)$ \\
\hline 86 & $\begin{array}{l}\text { Prussik on } \\
\text { doubled rope }\end{array}$ & Blue Streak & 1000 & 5 & $0.03(0.00)$ & $7.52(0.19)$ \\
\hline 86 & $\begin{array}{l}\text { Prussik on } \\
\text { single rope }\end{array}$ & Blue Streak & 1000 & 5 & $0.09(0.04)$ & $6.52(0.37)$ \\
\hline 86 & $\begin{array}{l}\text { Ascender and } \\
\mathrm{VT}^{\mathrm{z}}\end{array}$ & Velocity & 1000 & 10 & $2.38(1.57)$ & $6.07(0.97)$ \\
\hline
\end{tabular}

${ }^{\mathrm{z}}$ Valdotain Tresse used to back up the ascender.

\section{DISCUSSION}

The drop tests clearly demonstrated the incompatibility of toothed ascenders on the arborist climbing lines that were tested. This was expected since the Ascension is a positioning device (Type B in the EN 12841-2006 Standard) not a fall arrest device (Type A in the EN 12841-2006 Standard) (Petzl 2010). Product literature from another manufacturer also cautioned against subjecting ascenders to falls and impact loads (Kong 2010). Modifications made to the test to simulate arboricultural conditions do not appear to have radically influenced results since the arrest distance of Super Static, which meets the NFPA 1983 Standard (Anonymous 2006c), met the EN 12841-2006 Standard for Type B rope grabs (Anonymous 2006b). Although other common toothed ascenders and arborist climbing ropes were not tested, in the absence of robust empiric data to the contrary, it seems prudent to assume that similar results would have been found. It also seems prudent that the Z.133 Safety Standard (Anonymous 2006a) should formally address the use of ascenders in tree climbing.

On Tachyon and Velocity, ascenders stripped the outer sheath of fibers and slid it along the core fibers (Figure 3). Bunching of the outer sheath appeared to slow and eventually stop the ascender's descent, but the arrest distance for nearly all tests exceeded $2 \mathrm{~m}$. On Blue Streak and Safety Blue, as- cenders similarly cut and stripped the outer fibers of the rope, which also bunched and slowed the descent; in some tests, only a few of the inner strands of the rope remained (Figure 3). The core fibers in Tachyon and Velocity visually appeared to be undamaged after many tests. The core fibers may have provided some measure of safety if the climber were suspended on the damaged rope. On Blue Streak and Safety Blue, however, the remaining inner fibers (which function primarily to maintain a round cross section when the rope is under load) may have provided less support to a suspended climber, because of their small residual diameter (approximately $5 \mathrm{~mm}$ ) and, presumably, lower breaking strength. Bunching of the outer sheath of abrasion resistant fibers in Super Static also appeared to slow and stop the ascender's descent on that rope. Super Static is much stiffer than any of the arborist ropes tested, owing to its construction [pick angle, braid type, and heat treatment to reduce sheath slippage (Sterling Rope 2010)]. Super Static is also made entirely of nylon and fits the strict definition of a kernmantle rope according to the EN 1891-1998 Standard (Anonymous 1998). The construction and nylon fibers of Super Static were presumably responsible for its compliance with the arrest distance requirement from the EN 12841-2006 Standard for Type B rope grabs (Anonymous 2006b). Super Static, and other ropes that are appropriate to use with the Ascension 
[e.g., Edelweiss Rescue and Beal Antipodes (Petzl 2010)], however, do not meet the Z.133 Standard (Anonymous 2006a) for appropriate climbing lines because they are made of nylon.

It was unclear why the arrest distance for Tachyon, but none of the other ropes, was greater with $1000 \mathrm{~mm}$ of rope length compared to $2000 \mathrm{~mm}$ of rope length. Greater arrest distances with less rope in the system were physically intuitive since less rope in the system decreases the amount of kinetic energy of the falling mass that would be converted to strain energy stored in the rope (Smith 1998). By this reasoning, however, the impact load for tests of Tachyon with $1000 \mathrm{~mm}$ of rope length should have exceeded the impact load for tests of Tachyon with $2000 \mathrm{~mm}$ of rope length, which did not occur. This and other inconsistencies (e.g., greater and lesser impact loads with $1000 \mathrm{~mm}$ compared to $2000 \mathrm{~mm}$ of rope length for Safety Blue and Blue Streak, respectively) may be attributed to the complicating effect of the ascender cutting the rope. An initial speculation that variation in arrest distance among ropes and rope lengths caused stopping acceleration (and thus impact force) to vary did not fit with the observation that on every test maximum axial strain in the branch occurred immediately after the mass was released. Assuming maximum impact load coincided with maximum strain, impact load seemed more likely to be related to the ease with which the rope was cut rather than the arrest distance. It was also possible that sampling for impact loads at $60 \mathrm{~Hz}$ introduced bias; the EN 12841-2006 Standard

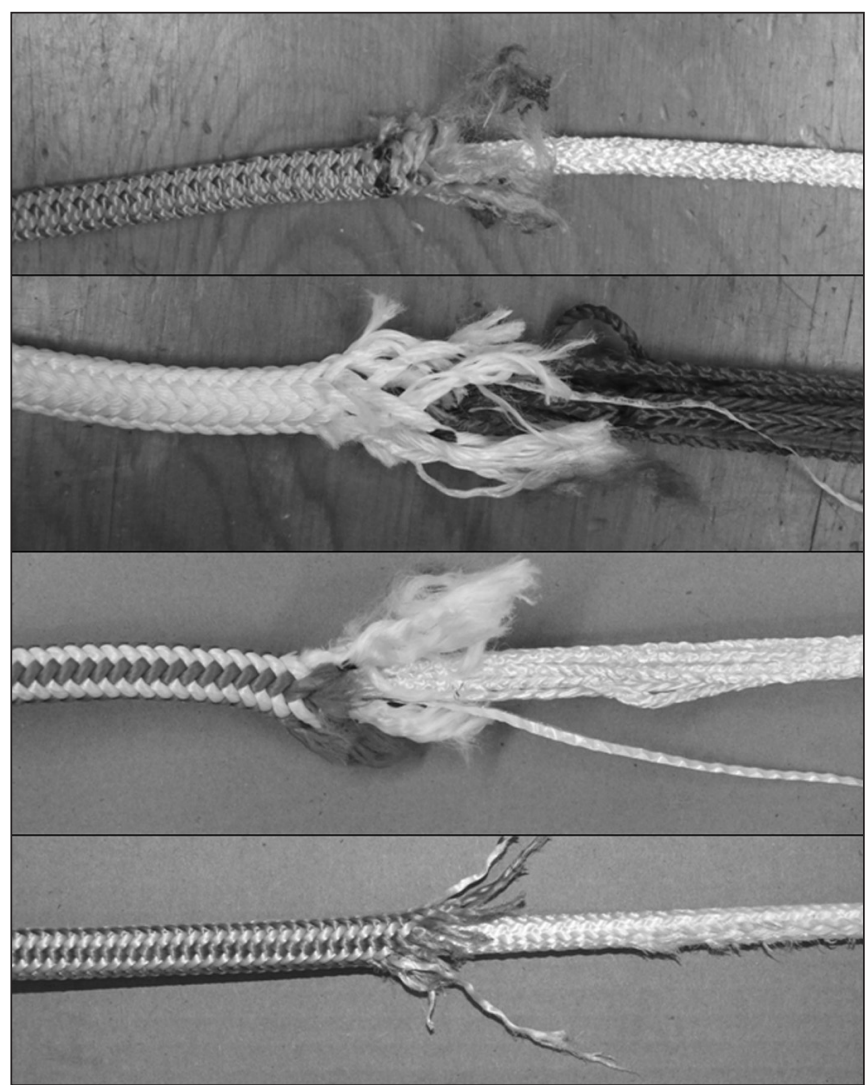

Figure 3. Cut ropes at the point where the ascender was initially attached to the rope, showing remain inner strands of rope. From top to bottom: Tachyon, Safety Blue, Blue Streak, Velocity.
(Anonymous 2006b) requires sampling at $1000 \mathrm{~Hz}$, so it is possible that impact loads do not reflect the absolute maximum value.

Impact loads at failure for arborist ropes were less than the $6.5 \mathrm{kN}$ for ropes $13 \mathrm{~mm}$ in diameter noted in product literature (Petzl 2010). This difference likely reflects the ease with which the ascender cut the rope, and the smaller mass used in the test. Impact loads were within the range of values presented by Bridge and Cowell (2009). Backing up the ascender with a friction hitch, as commonly shown in popular literature (Tresselt 2006; Adams 2007; Clark 2009), did not meaningfully affect arrest distance, but it appeared to increase impact load, a negative outcome. Part of this disparity was presumably due to the fact that the VT was only mildly tightened prior to the drop test, which made the knot effective in only three of ten tests. The VT was intentionally not vigorously tightened prior to testing, to simulate what could happen to a friction hitch during a footlock, as the ascender pushed the hitch up the rope. Unless the climber repeatedly set the VT, it would likely be somewhat loose after ascending some distance. The backup friction hitch may still provide a measure of safety against other types of accidents, for example, the ascender becoming dislodged from the rope by a branch. Impact loads for tests with Prusik loops were within the range of values presented by Bavaresco (2002).

In addition to the limitation of the sampling rate of the dynamometer, the accuracy of impact loads may have been limited by two other aspects of the experiment. First, attaching the lanyard to the drop mass with a carabiner allowed the possibility of cross-loading the carabiner. Second, branch deflection during testing would have stored strain energy converted from kinetic energy of the falling mass once the rope and branch begin to slow the descent of the mass. Neither of these limitations was considered serious because cross-loading was only observed on a few tests and branch deflection, which was conservatively estimated, was minimal. In practice, branches to which ropes would be attached would likely be smaller in diameter, but the rope would be placed closer to the point of attachment to the trunk. The variability of parameters that affect branch deflection (diameter, angle of orientation, elastic modulus, distance between rope and branch attachment) with respect to installing a climbing line precludes speculation about the effect of branch deflection on the conversion of kinetic to strain energy stored in the branch.

It is important to remember that the drop test represents a "worst-case scenario," and manufacturers (Kong 2010; Petzl 2010) and popular literature (Bridge and Cowell 2009) warn against dynamically loading toothed ascenders. In spite of the worst-case scenario nature of the drop test, it remains one of the tests that must be passed in order to meet the EN 12841-2006 Standard for Type B rope grabs (Anonymous 2006b). Tree climbers must be made aware that the use of some (and presumably most) arborist climbing ropes does not comply with the Ascension and, presumably, most toothed ascenders. More generally, climbers should be made aware that adopting and adapting techniques and gear from related high angle disciplines comes with the critical caveat that such techniques and gear do not always safely translate into use in arboriculture. Such information should be widely disseminated and emphasized in popular literature, at climbing demonstrations and competitions, and in training venues. 
Acknowledgments. The author gratefully acknowledges Kyle McCabe, Alex Sherman, and Joseph Scharf (University of Massachusetts-Amherst) for assisting with data collection; Michel Goulet (Petzl) and Sam Morton (Sterling Ropes) for donating material; Rick Vance (Petzl), Ed Carpenter (N.A.T.S.),

Dave Custer (M.I.T.), and two anonymous reviewers for suggesting helpful revisions to previous drafts; and the TREE Fund, which partially supported this project through a Hyland Johns grant.

\section{LITERATURE CITED}

Adams, M. 2007. Safe and efficient tree ascent: Doubled rope techniques (DdRT). Arborist News 16(3):50-54.

Anonymous. 1997. Mountaineering equipment—Rope clamps-Safety requirements and test methods. British Standards Institution, London. 9 pp.

Anonymous. 1998. Personal protective equipment for the prevention of falls from a height - Low stretch kernmantel ropes. British Standards Institution, London. $20 \mathrm{pp}$.

Anonymous. 2006a. American National Standard for Arboricultural Operations: Safety Requirements. American National Standards Institute, NY, New York. 55 pp.

Anonymous. 2006b. Mountaineering equipment-Rope clamps-Safety requirements and test methods. British Standards Institution, London. 9 pp.

Anonymous. 2006c. NFPA 1983: Standard on Life Safety Rope and Equipment for Emergency Services. National Fire Protection Association, Quincy, MA. 25 pp.

Bavaresco, P. 2002. Ropes and friction hitches used in tree climbing operations. Accessed October 1, 2010. <www.forestry.gov.uk/pdf/ FCRR-JD-0402.pdf/\$file/FCRR-JD-0402.pdf>

Blair, D.F. 1995. Arborist Equipment: A Guide to the Tools and Equipment of Tree Maintenance and Removal. International Society of Arboriculture, Champaign, IL. 291 pp.

Bridge, M., and C. Cowell. 2009. Safer ascent into trees. Arborist News 18(5):46-50.

Clark, J. 2009. The single-handled dual ascender: A concept device. Tree Care Industry 20(11):10-17.

Dunlap, T. 2002. The single rope technique. Tree Care Industry 13(9):32-36.

James, K.R., and B. Kane. 2008. Precision digital instruments to measure dynamic wind loads on trees during storms. Agriculture and Forest Meteorology 93:1361-1369.

Jepson, J. 1995. A new climbing technique. Tree Care Industry 6(2):30-33.

Jepson, J. 2000. The Tree Climber's Companion. 2nd Edition. Beaver Tree Publishing, Longville, MN. 104 pp.

Kim, S., and A.S. Nowak. 1997. Load distribution and impact factors for I-girder bridges. Journal of Bridge Engineering 2:97-104.

Kong. 2010. Carabiners, Climbing Gear, \& Safety Equipment. Accessed December 1, 2010. <http://www.kong.it/doc406.htm>

Lardner, T.J., and R.R. Archer. 1994. Mechanics of Solids. McGraw Hill, NY, New York. 802 pp.

Petzl. 2010. Product specifications for Ascension ascender. Accessed October 1，2010. <http://petzl.com/files/all/technical-notice/Pro/ B17WS_ascension_B175000J.pdf>
Smith, R.A. 1998. The development of equipment to reduce risk in rock climbing. Sports Engineering 1:27-39.

Sterling Rope. 2010. Guide to rope engineering, design, and use. Volume 1. Accessed October 1, $2010<\mathrm{http} / / /$ sterlingrope.com/media/document/techmanual.pdf>

Tresselt, T. 2006. A systematic approach for testing new equipment and techniques. Arborist News 15(1):51-53.

Werner, T.C. 1998. Elasto-plastic Impact of a Cantilever Beam Using Non-Linear Finite Elements and Event Simulation. M.S. Thesis. Department of Mechanical Engineering, Youngstown State University, Youngstown, OH. $66 \mathrm{pp}$.

\section{Brian Kane}

MA Arborists Association Professor

Department of Environmental Conservation

University of Massachusetts

Amherst, MA 01003, U.S

Résumé. Les élagueurs utilisent des bloqueurs pour grimper aux arbres, à la fois en tant que substitut aux anneaux de Prussik employés pour la montée en footlock à double corde ou la montée au moyen d'une corde simple. Les manufacturiers, cependant, ont établi des limites explicites par rapport à l'emploi des bloqueurs, limites qui sont souvent violées lorsqu'ils sont utilisés en montée dans les arbres. Des bloqueurs ont été testés avec quatre cordes différentes de montée pour les élagueurs au moyen d'un test de chute dynamique; l'impact de la charge et la distance d'arrêt ont été mesurés. Des 67 tests effectués, la distance d'arrêt a rencontrée celle décrite dans la norme EN 12841-2006, soit $\leq 2 \mathrm{~m}$, seulement 10 fois. Les impacts moyens de charge étaient de plus de $5 \mathrm{kN}$ et l'ajout d'un nœud autobloquant au bloqueur accroissait l'impact de la charge de plus de $6 \mathrm{kN}$. Les élagueurs ont besoin d'être informés quant à la manière appropriée d'utiliser les bloqueurs et aussi de n'employer ces derniers qu'avec des cordes appropriées à cet effet.

Zusammenfassung. Kletterer verwenden zunehmend mehr Steighilfen als einen Ersatz für die Prussik-Schlingen in der FußschlußHaltung am Doppelseil oder in der Einfach-Seil-Technik.Die Hersteller haben aber explizite Begrenzungen für die Einsatz von Aufstieghilfen, von denen viele während des Gebrauchs im Baum überschritten werden. Die Aufstiegshilfen wurden an vier Kletterseilen in einem dynamischen Falltest untersucht, wobei der Lasteintrag und die Distanz zum Haltepunkt gemessen wurden. Von 67 Tests wurde der Haltepunkt aus dem Standart $\leq 2 \mathrm{~m}$ nur 10mal erreicht. Der Lasteintrag lag duchschnittlich bei $5 \mathrm{kN}$, wenn ein Friktionshaken hinzugefügt wurde, stieg die Last auf mehr als $6 \mathrm{kN}$. Kletterer müssen sich bewußt machen, daß sie für die Steighilfen die richtige Technik verwenden und nur kompatible Seile nutzen.

Resumen. Los trepadores están incrementando el uso de ascensores para acceder a los árboles, tanto como un substituto de las cuerdas Prúsicas usadas en presa de pie con doble cuerda como con la técnica de la cuerda sola. Los fabricantes, sin embargo, tienen limitaciones explícitas sobre el uso de ascensores, muchos de los cuales son violatorios cuando se usan en la trepa de un árbol. Los ascensores fueron probados en cuatro cuerdas de trepa en una prueba de caída dinámica; carga de impacto y distancia. De 67 pruebas, la distancia llenó el Standar EN 12841-2006 $(\leq 2 \mathrm{~m})$ solamente 10 veces. Las cargas de impacto promediaron más de cinco $\mathrm{kN}$, añadiendo la fricción del nudo al ascensor un incremento a la carga de impacto de más de seis $\mathrm{kN}$. Los trepadores necesitan estar más atentos al uso apropiado de ascensores, y su uso solamente con las cuerdas compatibles. 